\title{
INCREASING FODDER BEET PRODUCTIVITY BY INTERCROPPING WITH SOME FIELD CROPS Rajab, Magda N. ${ }^{1}$; Azza Kh. Salem ${ }^{1}$ and A.M. Abdel-Galil ${ }^{2}$ 1- Forage Crops Research Dept., Field Crops Research Institute, Agricultural Research Center, Egypt \\ 2- Crop Intensification Research Dept., Field Crops Research Institute, Agricultural Research Center, Egypt
}

\section{ABSTRACT}

A two-year study was carried out at Sids Agricultural Experiments and Research Station, A.R.C., Beni - Sweif Governorate, Egypt during 2009/2010 and 2010/2011 winter seasons to investigate the possibility of increasing fodder beet productivity and net return per unit area by intercropping fodder beet with some field crops for encouraging Egyptian farmers to grow fodder beet in their fields. Fodder beet plants were grown in one row on all ridges $(60 \mathrm{~cm}$ width) with intercropping barley, wheat or faba bean plants on the other side of the first and third ridges. Also, fodder beet plants were grown in both side of beds $(120 \mathrm{~cm}$ width) with intercropping barley, wheat or faba bean plants in the middle of second and forth beds in addition to sole plantings of all the tested field crops. A split plot design in randomized complete block design in four replications was used. The results can be summarized as follows: Intercropping barley, wheat and faba bean with fodder beet led to decrease in yields of all tested field crops in comparison with sole plantings of these crops. As a result of intercropping, root yield of fodder beet was decreased by $18.44,17.10$ and $17.78 \%$ in the $1^{\text {st }}$ and $2^{\text {nd }}$ seasons and the combined analysis, respectively, as compared with sole fodder beet. Growing fodder beet on ridges (60 cm width) under intercropping and sole cultures had higher values of all the studied traits of fodder beet than those gown on beds $(120 \mathrm{~cm}$ width) , whereas, yields of barley, wheat and faba bean were not affected. The interaction between cropping systems and ridge width was not significantly affect all the studied traits of all the tested crops.

For competitive relationships, intercropping fodder beet with barley, wheat and faba bean increased land equivalent ratio (LER) as compared to sole fodder beet LER ranged from 1.05 to 1.22 with an average of 1.11 . All values of relative crowding coefficient $(\mathrm{K})$ exceeded 1.00 . $\mathrm{K}$ of barley, wheat or faba bean was higher than those of fodder beet. With respect to dominance analysis, barley, wheat or faba bean plants are dominant components and fodder beet plants are dominated components.

Intercropping fodder beet with barley, wheat and faba bean increased total and net returns by about 8.98 and 11.02 per cent, respectively, as compared with sole fodder beet. Net return of intercropping fodder beet with barley, wheat and faba bean was 8903,9015 and 14075 L.E. per faddan as compared with sole fodder beet (9605 L.E.). Growing fodder beet with faba bean plants on ridges $(60 \mathrm{~cm}$ width) gave the highest financial return as compared with sole fodder beet. This study concluded that growing fodder beet plants in one row on all ridges (60 cm width) with intercropping faba bean plants on the other side of the first and third ridges gave high yield of fodder beet.

Keywords: Intercropping; Fodder beet; Barley; Wheat; Faba bean; Competitive relationships; Financial return.

\section{INTRODUCTION}

Egyptian forage crops production is very important for successful animal production which is severely limited by marked seasonal feed deficits. 
These crops mainly fresh berseem during winter and as hay during summer represents about $60 \%$ of available local feed. Summer forage crops such as Darawa, millet, sorghum, cowpea, Sudan grass, and corn silage represent about $5 \%$ of the available local feed. Alfalfa which provides feed all the year around represents about $5 \%$ of the available local feed (El-Nahrawy, 2011).

Accordingly, there is a shortage in green forage supply during the summer season. Fodder beet (Beta vulgaris L.) is cultivated as an annual winter crop. It is one of the promising forage crops which is recommended as a good source for energy for dairy cows (Gaivoronskii, 1981).It offers a higher yield potential than any other "arable" fodder crop. The above and below growth parts (leaves and roots) are used to feed the animals but, the main fodder is tuberous roots (Ibrahim, 2005). The roots have an excellent feed quality and they are very palatable to ruminant stock. The leaf can be utilized if required to boost the total fodder output even further (Turk, 2010). Consequently, its cultivation may help in overcoming the problem of animal feeding in summer season; but the cultivated area is very limited and expects to be devoted to the cultivation of strategic food crops such as wheat (Triticum aestivum L.) and faba bean (Vicia faba L.) during winter season.

Also, cultivated barley (Hordeum vulgare L.) ranks fourth among the cereals in worldwide production. It is commonly used for animal feed and malting production (Finocchiaro et al., 2008). It is mostly grown by resourcepoor farmers in marginal environments, receiving modest or no inputs in Egypt. Moreover, Al-Karaki and Al-Hashimi (2012) mentioned that barley is the most commonly grown forage, because it usually gives the best yield of nutrients. They recorded the highest values in green fresh yields in cowpea followed by barley, alfalfa, sorghum, and wheat, respectively. However, the differences between the crops barley, cowpea, and alfalfa in green fresh fodder yields were not significant.

In view of the previous, it was necessary to find a modern agricultural technical practice in Egypt for the cultivation of this forage crop in the Nile Valley areas. Egyptian efforts are being focused on measures that lead to a significant increase in crop production per unit area. The successful implementation of two agricultural strategies in the 1980s and the 1990s had a positive economic impact at both macro and sector levels. Several different cropping patterns are followed in the Nile Valley and Delta areas, depending on the soil type and crops. Farmers are very responsive to technology transfer, extension activities and price incentives. Intercropping is recommended to increase total agriculture products in Egypt (Metwally, 1999). But fodder beet yield was reduced by intercropping (Abdel-Gwad et al., 2008). However, intercropping can be used as a tool to improve competitive ability of a canopy with good suppressive characteristics (Rezvani et al., 2011).

The objective of this study to investigate the possibility of increasing fodder beet productivity and net return per unit area by intercropping with wheat, faba bean or barley for encouraging Egyptian farmers to grow fodder beet. 


\section{MATERIALS AND METHODS}

Two experiments were carried out at Sids Agricultural Experiments and Research Station, A.R.C., Beni - Sweif Governorate (Lat. $29^{\circ} 12^{\prime}$ N, Long. $31^{\circ}$ 01' E, 32 m a.s.I.), Egypt during 2009/2010 and 2010/2011 winter seasons to investigate the possibility of increasing fodder beet productivity and net return per unit area by intercropping with some field crops for encouraging Egyptian farmers to grow fodder beet. Fodder beet variety 'Voroshenger' and three different field crops (barley variety 'Giza 29', wheat variety 'Beni - Sweif 1'and faba bean variety 'Misr 1') were used. Fig. 1 shows the treatments which were the combinations among cropping systems and ridge width as follows:

1. Planting fodder beet on one side of the ridges $(60 \mathrm{~cm}$ width) and planting one barley row on the other side of the fodder beet on the first and third ridge ( $100 \%$ fodder beet : $25 \%$ barley).

2. Planting fodder beet on one side of the ridges $(60 \mathrm{~cm}$ width) and planting one wheat row on the other side of the fodder beet on the first and third ridge ( $100 \%$ fodder beet : $25 \%$ wheat)

3. Planting fodder beet on one side of the ridges $(60 \mathrm{~cm}$ width) and planting one faba bean row on the other side of the fodder beet first and third ridge (100\% fodder beet: $25 \%$ faba bean)

4. Planting fodder beet on both sides of the beds $(120 \mathrm{~cm}$ width) and planting one barley row on middle of all fodder beet beds (100\% fodder beet : $25 \%$ barley).

5. Planting fodder beet on both sides of the beds $(120 \mathrm{~cm}$ width) and planting one wheat row on middle of all fodder beet beds (100\% fodder beet : $25 \%$ wheat)

6. Planting fodder beet on both side of the beds $(120 \mathrm{~cm}$ width) and planting one faba bean row on middle of all fodder beet beds $(100 \%$ fodder beet: $25 \%$ faba bean)

7. Sole fodder beet: Planting fodder beet on one side of the ridges $(60 \mathrm{~cm}$ width)

8. Sole barley: Planting two barley rows on both sides of the ridges $(60 \mathrm{~cm}$ width)

9. Sole wheat: Planting two wheat rows on both sides of the ridges $(60 \mathrm{~cm}$ width)

10.Sole faba bean: Planting two faba bean rows on both sides of the ridges (60 cm width)

Varieties of fodder beet, barley, wheat and faba bean kindly provided by Forage, Barley, Wheat and Food Legumes Res. Dept., Field Crops Res. Inst., ARC, respectively. The preceding summer crop was maize in both seasons. Normal cultural practices for growing all crops were used as recommended in the area. Fodder beet solid and in all intercropped crops was sown at the same date on 29 and $20^{\text {th }}$ October at 2009/2010 and 2010/2011 seasons, respectively.

Fodder beet plants were thinned to one plant/hill at $20 \mathrm{~cm}$ between hills under intercropping and sole cultures. Barley and wheat grains were drilled in one row in intercropping cultures and in two rows in sole cultures. 
Rajab, Magda N. et al.
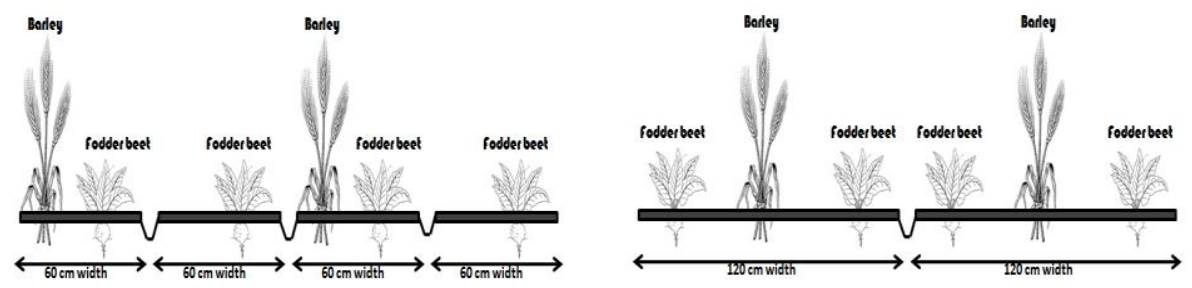

Intercropping fodder beet with barley
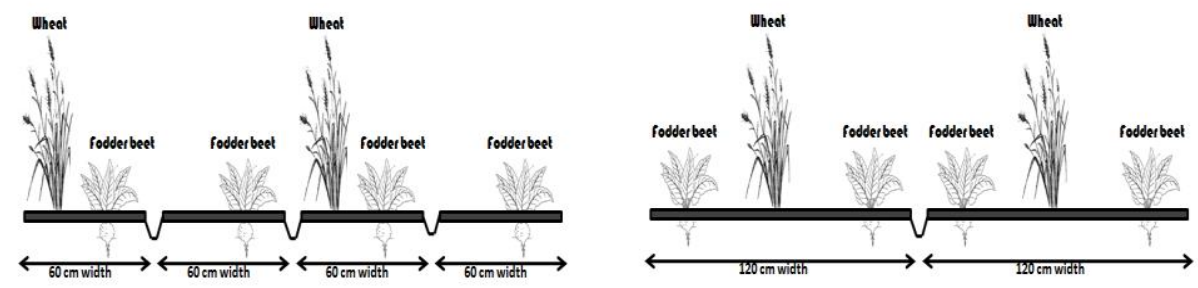

Intercropping fodder beet with wheal
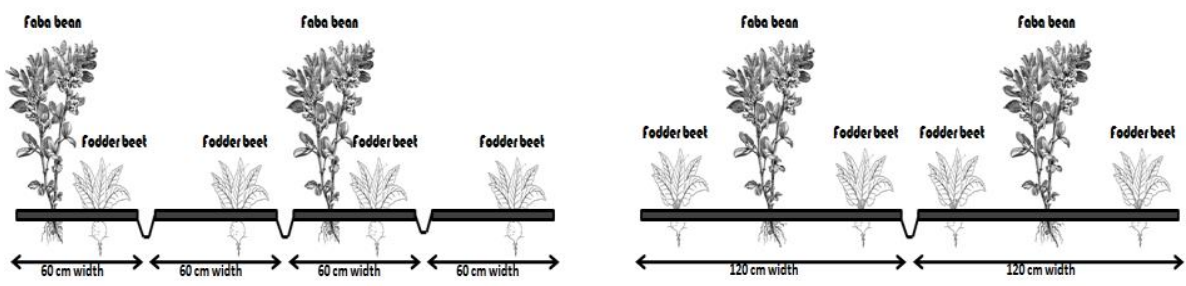

Intereropping fodder beet with faba bean

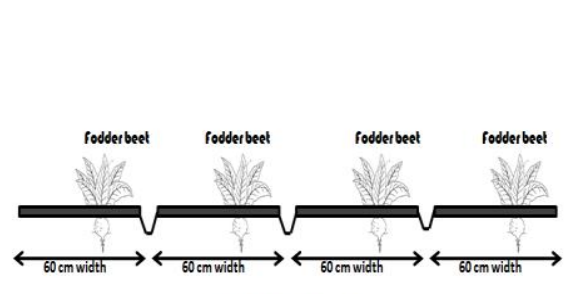

Sole fodder beel

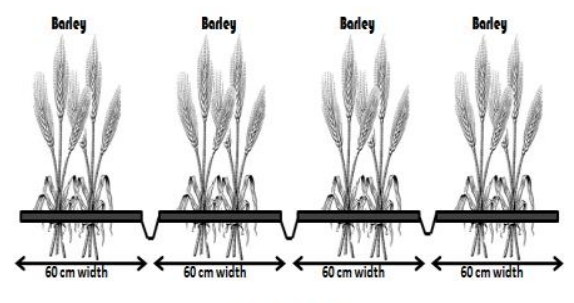

Sole barley

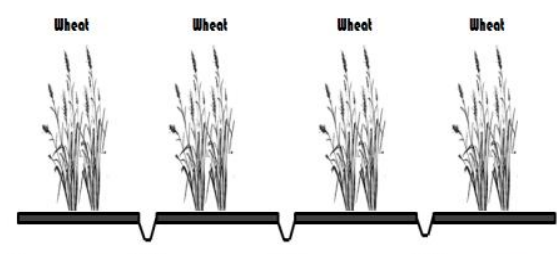

$\longleftrightarrow$ 60cm width $\longleftrightarrow \stackrel{60 \mathrm{~cm} \text { width }}{\longleftrightarrow} \stackrel{60 \mathrm{~cm} \text { widh }}{\longleftrightarrow} \stackrel{60 \mathrm{~cm} \text { width }}{\longrightarrow}$

Sole wheak

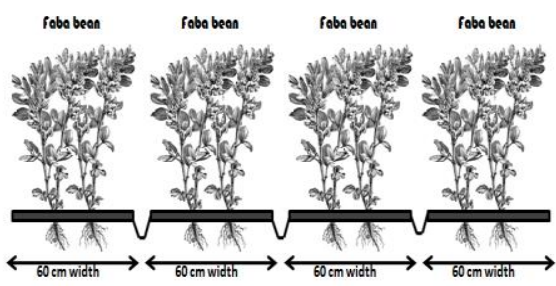

Sole faba bean

Fig.1: Intercropping barley, wheat and faba bean with fodder beet and sole cultures 
Faba bean plants were thinned to two plants/hill at $25 \mathrm{~cm}$ between hills. Recommended solid cultures of all the tested crops were used to estimate the competitive relationships. A split plot design in randomized complete block design in four replications was used. Cropping systems (intercropping and sole) were randomly assigned to the main plots, ridge width was allocated in sub plots. The area of sub-plot was $14.4 \mathrm{~m}^{2}$, it consisted of 8 ridges, and each ridge was $3.0 \mathrm{~m}$ in length and $0.6 \mathrm{~m}$ in width.

\section{Yield and its attributes}

At harvest, root length, diameter $(\mathrm{cm})$ and root weight/plant were measured on ten guarded plants from each plot, whereas, root yields (ton/faddan) were recorded on the basis of experimental plot area by harvesting all fodder beet plants of each plot. Grain yields of barley and wheat (ardab/faddan), as well as, seed yield of faba bean (ton/faddan) were recorded on the basis of experimental plot area

\section{Competitive relationships}

Land equivalent ratio (LER)

LER defined as the ratio of area needed under sole cropping to one of intercropping at the same management level to produce an equivalent yield (Mead and Willey, 1980). It is calculated as follows:

$\mathrm{LER}=\left(\mathrm{Y}_{\mathrm{ab}} / \mathrm{Y}_{\mathrm{aa}}\right)+\left(\mathrm{Y}_{\mathrm{ba}} / \mathrm{Y}_{\mathrm{bb}}\right)$

Where $Y_{a a}=$ Pure stand yield of crop a (fodder beet)

$\mathrm{Y}_{\mathrm{bb}}=$ Pure stand yield of crop $\mathrm{b}$ (barley, wheat or faba bean)

$Y_{a b}=$ Intercrop yield of crop a (fodder beet)

$\mathrm{Y}_{\mathrm{ba}}=$ Intercrop yield of crop b (barley, wheat or faba bean)

Relative crowding coefficient (RCC)

Relative crowding coefficient estimates the relative dominance of one species over the other in the intercropping system (Baniket al., 2006).It is calculated as follows: $\mathrm{RCC}=\mathrm{K}_{\mathrm{a}} \times \mathrm{K}_{\mathrm{b}}$

$\mathrm{K}_{\mathrm{a}}=\mathrm{Y}_{\mathrm{ab}} \times \mathrm{Z}_{\mathrm{ba}} /\left[\left(\mathrm{Y}_{\mathrm{aa}}-\mathrm{Y}_{\mathrm{ab}}\right) \times \mathrm{Z}_{\mathrm{ab}}\right]$

$K_{b}=Y_{b a} \times Z_{a b} /\left[\left(Y_{b b}-Y_{b a}\right) \times Z_{b a}\right]$

Where $Y_{a a}=$ Pure stand yield of crop a (fodder beet)

$\mathrm{Y}_{\mathrm{bb}}=$ Pure stand yield of crop $\mathrm{b}$ (barley, wheat or faba bean)

$\mathrm{Y}_{\mathrm{ab}}=$ Intercrop yield of crop a (fodder beet)

$\mathrm{Y}_{\mathrm{ba}}=$ Intercrop yield of crop b (barley, wheat or faba bean)

$Z_{a b}=$ The respective proportion of crop $a$ in the intercropping system (fodder beet)

$Z_{b a}=$ The respective proportion of crop $b$ in the intercropping system (barley, wheat or faba bean)

Aggressivity (Agg)

Aggressivity represents a simple measure of how much the relative yield increase in one crop is greater than the otherin an intercropping system (Ghosh et al., 2006).

$A_{a b}=\left[Y_{a b} /\left(Y_{a a} \times Z_{a b}\right)\right]-\left[Y_{b a} /\left(Y_{b b} \times Z_{b a}\right)\right]$

$A_{b a}=\left[Y_{b a} /\left(Y_{b b} \times Z_{b a}\right)\right]-\left[Y_{a b} /\left(Y_{a a} \times Z_{a b}\right)\right]$

Where $Y_{a a}=$ Pure stand yield of crop a (fodder beet)

$Y_{b b}=$ Pure stand yield of crop $b$ (barely, wheat or faba bean) 
$\mathrm{Y}_{\mathrm{ab}}=$ Intercrop yield of crop a (fodder beet)

$Y_{\mathrm{ba}}=$ Intercrop yield of crop b (barley, wheat or faba bean)

$Z_{a b}=$ The respective proportion of crop $a$ in the intercropping system (fodder beet)

$Z_{\mathrm{ba}}=$ The respective proportion of crop $\mathrm{b}$ in the intercropping system (barley, wheat or faba bean)

\section{Farmer's benefit}

It was calculated by determining the total costs and net return of intercropping culture as compared to recommended sole planting of fodder beet according to Metwally et al. (2009).

1. Total return of intercropping cultures $=$ Price of fodder beet yield + price of barley, wheat or faba bean yield (L.E.)

To calculate the total return, the average of barley, wheat and faba bean prices presented by Agricultural Statistics (2013) was used, while the average of fodder beet yield price presented by market price in 2011 season.

2. Net return/fad $=$ Total return - (fixed cost of fodder beet + variable costs of barley, wheat and faba bean according to intercropping pattern).

\section{Statistical Manipulation}

Analysis of variance of the obtained results of each season was performed. The homogeneity test was conducted of error mean squares and accordingly, the combined analysis of the two experimental seasons was carried out. The measured variables were analyzed by ANOVA using MSTATC statistical package (Freed, 1991). Mean comparisons were done using least significant differences (LSD) method at $5 \%$ level of probability to compare differences between the means (Gomez and Gomez, 1984).

\section{RESULTS AND DISCUSSION}

\section{Yield and its attributes}

\section{Cropping systems}

Intercropping fodder beet with barley, wheat or faba bean significantly affected root length and diameter, root weight/plant and root yield/fad in the two growing seasons and the combined analysis (Table 1). Intercropping barley, wheat or faba bean with fodder beet decreased root length and diameter, root weight/plant and root yield/fad in comparison with sole fodder beet. As a result of intercropping, root weight/plant and root yield/fad were decreased by 11.97 and $18.44 \%$ in the $1^{\text {st }}$ season, 8.95 and $17.10 \%$ in the $2^{\text {nd }}$ season, 10.86 and $17.78 \%$ in the combined analysis, respectively, as compared with sole fodder beet.

These data reveal that intercropping wheat or barley with fodder beet had a significant negative impact $(P \leq 0.05)$ on fodder beet plants as compared with those obtained by intercropping with faba bean. Obviously, intercropping legumes with fodder beet had lower adverse effects on yield of intercropped fodder beet than cereal crops under intercropping conditions. Legumes are plants that bear their seeds in pods. They differ markedly from grasses, cereals and other non-legume crops. Legumes in close association with nitrophilous crops have increased crop production (Waghmare and Singh, 1984). Because of their ability to biological nitrogen fixation, legumes 
are largely involved in nitrogen facilitation and nitrogen dynamic in the plant community and in agrosystems (Hauggaard-Nielsen and Jensen, 2005 and Fustec et al., 2010). These results are in accordance with those obtained by Abdel-Gwad et al. (2008) they showed that root yield of fodder beet were reduced significantly by intercropping with wheat as compared with sole fodder beet.

Also, intercropping barley, wheat or faba bean with fodder beet significantly affected grain yields of barley and wheat as well as seed yield of faba bean (Table 1). Intercropping barley with fodder beet decreased grain yield/fad by $70.40 \%$ in the $1^{\text {st }}$ season, $71.13 \%$ in the $2^{\text {nd }}$ season and $70.81 \%$ in the combined analysis. Also, intercropping wheat with fodder beet decreased grain yield/fad by $69.56 \%$ in the $1^{\text {st }}$ season, $70.12 \%$ in the $2^{\text {nd }}$ season and $69.86 \%$ in the combined analysis. Moreover, intercropping faba bean with fodder beet decreased seed yield/fad by $67.89 \%$ in the $1^{\text {st }}$ season, $68.59 \%$ in the $2^{\text {nd }}$ season and $68.33 \%$ in the combined analysis.

It is clear that decreasing plant population density of barley, wheat and faba bean to $25 \%$ of sole plantings of these crops decreased $(P \leq 0.05)$ grain and seed yields per unit area for these crops. The reduction in grain yield of wheat per fad was quite expected as a result of decreasing stand of intercropped wheat as reported by Abdel-Gwad et al. (2008). Similar results were obtained by Abou-Elela and Gadallah (2012) they indicated that seed yield of faba bean per faddan was reduced significantly by intercropping with fodder beet as compared with sole faba bean.

\section{Ridge width}

All the studied traits of fodder beet were significantly affected by ridge width, except root length and diameter in the $1^{\text {st }}$ season only, while, yields of barley, wheat and faba bean were not affected in both seasons (Table 1). Growing fodder beet on ridges (60 $\mathrm{cm}$ width) under intercropping and sole cultures had higher values of all the studied traits of fodder beet than those grown on beds (120 cm width), relatively. Growing fodder beet on ridges increased fodder beet weight/plant and fodder beet yield/fad by 0.75 and $1.16 \%$ in the $1^{\text {st }}$ season, 0.78 and $1.26 \%$ in the $2^{\text {nd }}$ season and 0.76 and $1.21 \%$ in the combined analysis, respectively, in comparison with that gown on beds under intercropping and sole cultures.

Obviously, decreasing ridge width from 120 to $60 \mathrm{~cm}$ slightly increased $(P \leq$ $0.05)$ fodder beet productivity per unit area. These results may be due to competition for basic resources between fodder beet and barley, wheat or faba bean was not pronounced between both patterns.

Interaction between cropping systems and ridge width

With respect to response of cropping systems to ridge width, all the studied traits of all the tested crops were not affected (Table1). These data show that each of these two factors act independently on all the studied traits of all the tested crops meaning that cropping systems responded similarly ( $P$ $>0.05$ ) to ridge width. These results are in harmony with those obtained by Mack (1979) who compared 6,12, 18, and 24-inch rows combined with three seeding rates of table beet. There was no interaction of row spacing and within-row seeding rate on yields. 
Rajab, Magda N. et al.

1

828 


\section{Competitive relationships \\ Land Equivalent Ratio (LER)}

Relative yields of fodder beet and barley, wheat or faba bean were affected significantly by the cropping systems in the two growing seasons and the combined analysis (Table 2). Intercropping fodder beet with faba bean had higher values of relative yields of fodder beet and intercrops as compared with intercropping fodder beet with barley or wheat. These data may be due to faba bean plants (as legume crop) have ability to biological nitrogen fixation, legumes are largely involved in nitrogen facilitation and nitrogen dynamic in the plant community and in agrosystems. Relative yield of fodder beet was significantly affected by ridge width, whereas, relative yield of intercrops was not affected in the two growing seasons and the combined analysis (Table 2). Growing fodder beet in ridges $(60 \mathrm{~cm}$ width) had higher relative yield of fodder beet than growing fodder beet in beds (120 $\mathrm{cm}$ width) under both intercropping and sole. Relative yields of fodder beet and barley, wheat or faba bean were significantly affected by the interaction between cropping systems and ridge width in the two growing seasons and the combined analysis except relative yield of fodder beet in the 1st season only (Table 2).Intercropping fodder beet with faba bean on ridges $(60 \mathrm{~cm}$ width) had higher values of relative yields of both crops, whereas, intercropping fodder beet with wheat had the lowest relative yield of both crops.

The values of land equivalent ratio (LER) were estimated by using data of recommended sole cultures of all crops. LER was affected significantly by the cropping systems in the two growing seasons and the combined analysis (Table 2). In general, intercropping fodder beet with barley, wheat and faba bean increased LER as compared to sole fodder beet (Table 2). It ranged from 1.05 (by intercropping fodder beet with wheat on beds, $120 \mathrm{~cm}$ width) to 1.22 (by intercropping fodder beet with faba bean on ridges, $60 \mathrm{~cm}$ width) with an average of 1.11. The advantage of the highest LER by intercropping fodder beet with faba bean over the others could be due to faba bean plants (as legume crop) have ability to biological nitrogen fixation, legumes are largely involved in nitrogen facilitation and nitrogen dynamic in the plant community and in agrosystems. It is clear that plant population density of fodder beet and barley, wheat or faba bean played a major role in increasing productivity per unit area under intercropping culture where it reached 100 and $25 \%$ of sole plantings, respectively. Similar results were obtained by Abdel-Gwad et al. (2008) they found that Intercropping fodder beet with wheat increased land equivalent ratio in the average of both seasons by 1.21 , $1.07,1.15$ and 1.22, when adding 70, 90, 110 and $130 \mathrm{~kg} \mathrm{~N}$ fertilizer/fad respectively. Also, Abou-Elela and Gadallah (2012) reported that LER was higher by intercropping faba bean with fodder beet than those of sole plantings. 
Rajab, Magda N. et al.

2

830 


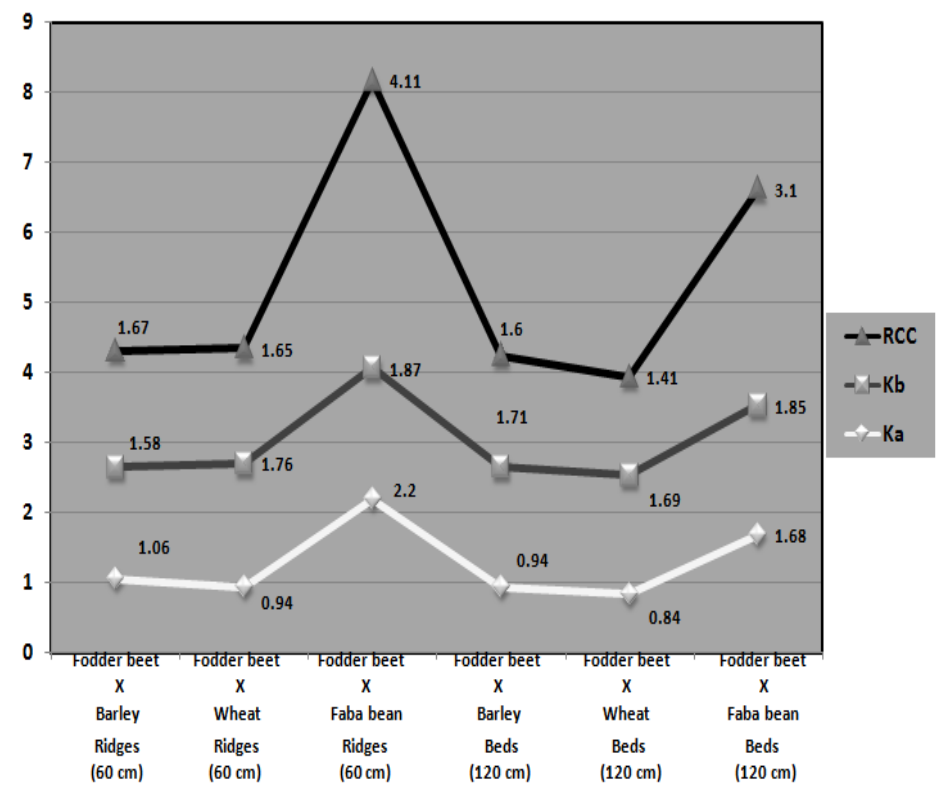

Fig. 2. Relative crowding coefficient (RCC) as affected by the intercropping system, ridge

With respect to ridge width, LER was significantly affected by ridge width in the two growing seasons and the combined analysis (Table 2). Growing fodder beet on ridges (60 $\mathrm{cm}$ width) gave the highest LER than those grown on beds $(120 \mathrm{~cm}$ width) under both intercropping and sole cultures.

LER was significantly affected by the interaction between cropping systems and ridge width in the two growing seasons and the combined analysis (Table 2). Intercropping fodder beet with faba bean on ridges (60 $\mathrm{cm}$ width) gave the highest LER in the two growing seasons and the combined analysis, whereas, the lowest LER was obtained by growing fodder beet with wheat in the two growing seasons and the combined analysis.

\section{Relative crowding coefficient (RCC)}

The relative dominance of one species over the other in this intercropping study was estimated by the use of relative crowding coefficient (RCC). When the value of relative crowding coefficient (Rcc) is greater than 1.00 , there is intercrop advantage; when RCC is equal to 1.00 , there is no yield advantage; when RCC is lesser than 1.00, there is a disadvantage. Table 3 and Fig. 2 shows that all values of the total relative crowding coefficient (RCC) were exceeded 1.00. Relative crowding coefficient of barley, wheat or faba bean was higher than those of fodder beet. The lowest RCC was obtained from intercropping fodder beet with wheat on beds (120 $\mathrm{cm}$ width), whereas, intercropping fodder beet with faba bean on ridges (60 $\mathrm{cm}$ width) gave the highest RCC in the combined data across 2009/2010 and 2010/2011 seasons. 


\section{Aggressivity (Agg)}

Aggressivity determines the difference in competitive ability of the component crops in intercropping association. The positive sign indicates the dominant component and the negative sign indicates the dominated component. Higher numerical values of aggressiveness denote greater difference in competitive ability, as well as, bigger difference between actual and expected yield in both crops. The results indicate that the value of aggressivity of barley, wheat and faba bean was positive for all treatments, whereas, the values of aggressivity was negative for all intercropped fodder beet in the combined data across 2009/2010 and 2010/2011 seasons ( Table 3 and Fig. 3). These data show that barley, wheat or faba bean are dominant component and fodder beet plants are dominated component.

In general, the highest negative values were obtained by growing fodder beet with barley or wheat plants, whereas, intercropping fodder beet with faba bean had the lowest negative values. These results clear that intercropping fodder beet with barley or wheat is more aggressive than intercropping fodder beet with faba bean.

\section{Economic evaluation}

Intercropping fodder beet with barley, wheat and faba bean increased total and net returns by about 8.98 and 11.02 per cent, respectively, as compared with sole fodder beet (Table 4). Net return of intercropping fodder beet with barley, wheat and faba bean was 8903, 9015 and 14075L.E. per faddan as compared with sole fodder beet ( 9605 L.E.). Intercropping fodder beet with faba bean in ridges $(60 \mathrm{~cm}$ width) gave the highest financial value when using high population densities of both crops which reached 100 and $25 \%$ of sole fodder beet and faba bean, respectively. The study indicated that intercropping fodder beet with faba bean is more profitable to farmers than sole fodder beet by using suitable intercropping pattern. These results are in harmony with those obtained by Abdel-Gwad et al. (2008) they reported that the highest return between growing fodder beet as sole crop and its growing with wheat was collected when adding $130 \mathrm{~kg} \mathrm{~N} / \mathrm{fad}(2718.80$ L.E.). 
J. Plant Production, Mansoura Univ., Vol. 5 (5), May, 2014

833 


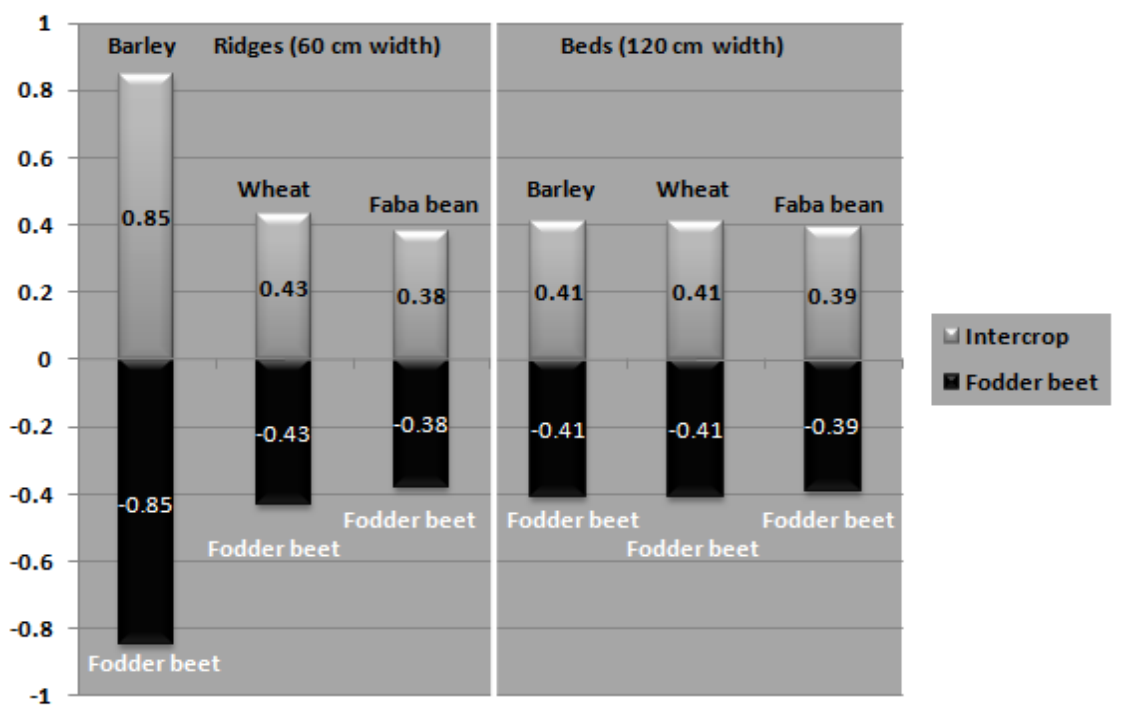

Fig. 3. Aggressivity as affected by the intercropping system, ridge width and their width and their interaction (combined data across 2009/2010 and 2010/2011 seasons) interaction (combined data across 2009/2010 and 2010/2011 seasons)

\section{CONCLUSION}

It could be concluded that although intercropping pattern resulted in adverse effects on intercropped fodder beet yield and its attributes, however, Egyptian farmers could achieve an increase in their income by about $50 \%$ as compared to sole fodder beet when growing fodder beet with faba bean on ridges $(60 \mathrm{~cm}$ width). This paper emphasizes there is a critical need for several scientific studies including morphological and physiological characteristics to increase the productivity of intercropped fodder beet with minimizing the adverse effects of shading intercropped barley, wheat or faba bean crops which reflected positively on the financial return of fodder beet's farmer.

\section{REFERENCES}

Abdel-Gwad, M.S.A.; Abd El-Aziz, T.K.A. and Abd El-Galil, A.M. (2008).Effect of intercropping wheat with fodder beet under different levels of $\mathrm{N}$ application on yield and quality. Ann. Agric. Sci., 53: $353-362$.

Abou-Elela, A.M. and Gadallah, R.A. (2012). Effect of transplanted seedling age of intercropped fodder beet with faba bean and nitrogen fertilizer levels on yield and it's component of fodder beet and faba bean. Zagazig J. Agric. Res., 39 (6): 1057 - 1067.

Agriculture Statistics (2013).Winter Crops. Agriculture Statistics and Economic Sector, $1^{\text {st } E d ., ~ M i n i s t r y ~ o f ~ A g r i c u l t u r e ~ a n d ~ L a n d ~ R e c l a m a t i o n, ~}$ Egypt. 
Al-Karaki, G.N. and Al-Hashimi, M. (2012).Green fodder production and water use efficiency of some forage crops under hydroponic conditions. ISRN Agronomy, (2012): 1 - 5.

Banik, P.; Midya, B.K.; Sarkar and Ghose, S.S. (2006). Wheat and chickpea intercropping systems in an additive series experiment: advantages and weed smothering. Eur. J. Agron., 24: $325-332$.

El-Nahrawy, M.A. (2011). Country Pasture/Forage Resource Profiles: Egypt. Food and Agriculture Organization of the United Nations, Rome, Italy.

Finocchiaro, F.; Gianinetti, A.; Ferrari, B. and Stanca, A.M. (2008).Effect of beta-glucans and starch type on glycaemic response after consumption of barley breed. proc. $10^{\text {th }}$ International Barley Genetics Symposium, ICARDA, Alexandria, Egypt: $584-588$.

Freed, R.D. (1991).MSTATC Microcomputer Statistical Program. Michigan State Univ., East Lansing, Michigan, USA.

Fustec, J.;Lesuffleur, F.; Mahieu, S.and Cliquet, J.B. (2010).N rhizodeposition of legumes. A review. Agron. Sustain Dev., 30:57-66.

Gaivoronskii, B.A. (1981). Tubers in diet for cows. Poferativnyi Zhrnal, 58: 12 - 15. Nut. Abstr. and Rev., 5: 768 (CF Computer Search).

Ghosh, P.K.; Manna, M.C.; Bandyopadhyay, K.K.; Ajay, K.; Tripathi, A.K.; Wanjari, R.H.; Hati, K.M.; Misra, A.K. and AcharyaSubbaRao, C.L. (2006). Interspecific interaction and nutrient use in soybean/sorghum intercropping system. Agron. J., 98: 1097 - 1108.

Gomez, K.A. and Gomez, A.A.(1984).Statistical Procedures for Agricultural Research. John Eilley and Sons, Inc. New York.

Hauggaard-Nielsen, H. and Jensen, E.S. (2005).Facilitative root interactions in intercrops. Plant Soil, 274:237-250.

Ibrahim, Y.M. (2005). Ranges and forage (In Arabic). Dar Azza for Publication, Khartoum, Sudan, 300p (CF Computer Search).

Mack, H.J. (1979). Effects of row spacings, fertilizers, and harvest dates on table beets. J. Amer. Soc. Hort. Sci., 104:717-720 (CF Computer Search).

Mead, R. and Willey, R.W. (1980).The concept of a "land equivalent ratio" and advantages in yields from intercropping. Exp. Agric., 16: 217 228.

Metwally, A.A. (1999). Intensive cropping system in the battle against food crises. Proc. $1^{\text {st }}$ Conf. in Recent technologies, Fac. Agric, Cairo Univ., 27- 29 Nov., 11: $333-341$.

Metwally, A.A.; Shafik, M.M.; EL-Habbak, K.I. and Abdel-Wahab, Sh.I. (2009). Step forward for increasing intercropped soybean yield with maize. The $4^{\text {th }}$ Conf., Recent Technologies in Agric., 3-5 Nov., Cairo Univ., 2: $256-269$.

Rezvani, M.; Zaefarian, F.; Aghaalikhani, M.; Rahimian Mashhadi, H. and Zand, E. (2011).Investigation corn and soybean intercropping advantages in competition with redroot pigweed and jimsonweed. World Academy of Science, Engineering and Technology, 5: 9-21. 
Turk, M. (2010). Effects of fertilization on root yield and quality of fodder beet (Beta vulgaris var. Crassamansf.). Bulgarian J. Agric. Sci., 16 (2): 212 - 219 (CF Computer Search).

Waghmare, A.B. and Singh, S.P. (1984). Sorghum-legume intercropping and the effects of nitrogen fertilization. I. Yield and nitrogen uptake by crops. Exp. Agric., 20:251 - 259.

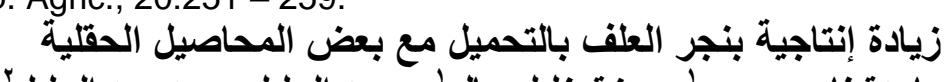

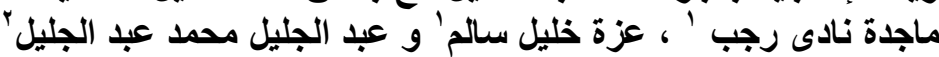

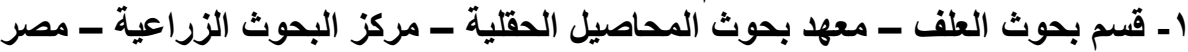

r - قسم بحوث التكثيف المحصولى ـ معهد بحوث المحاصيل الحقلية ـ مركز البحوث الزيلية الزراعية ـ

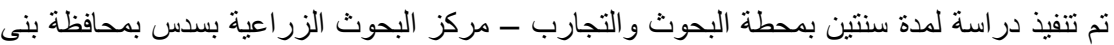

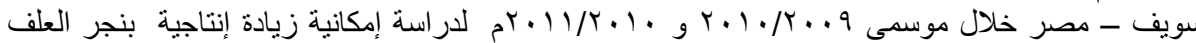

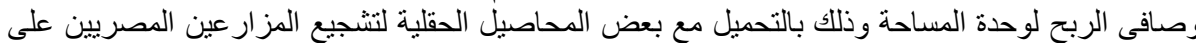

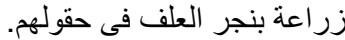

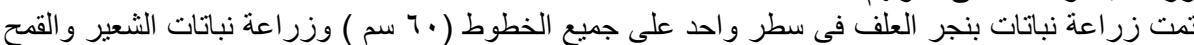

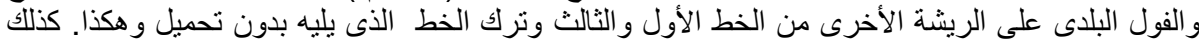

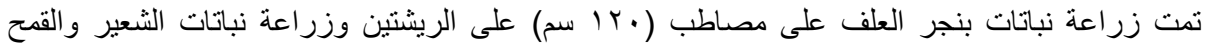

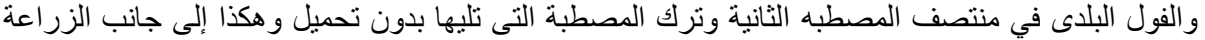

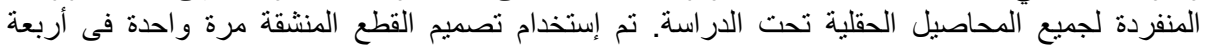
مكررات ، ويمكن تلخيص أهم النتائج فيما يلى الئي

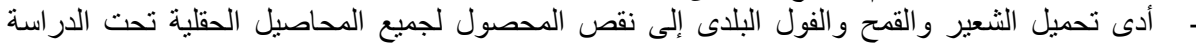

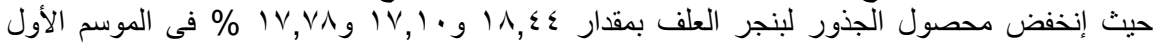

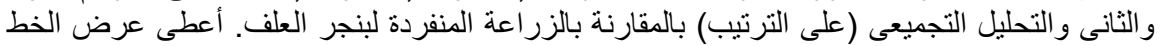

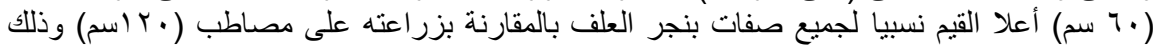

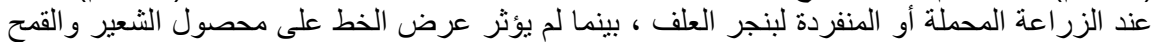

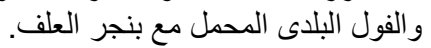

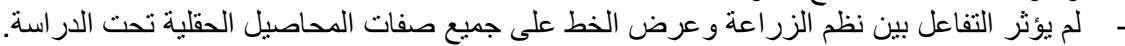

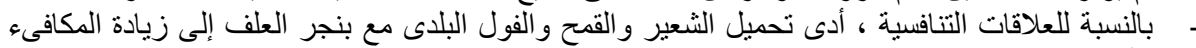

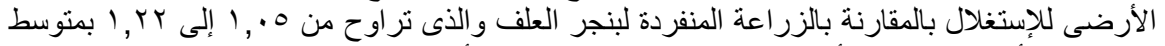

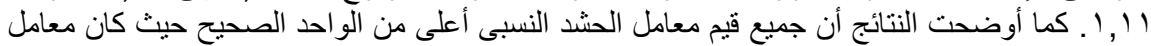

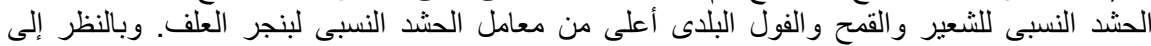

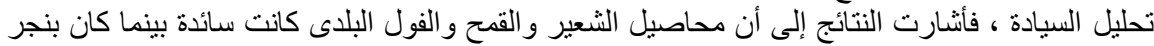

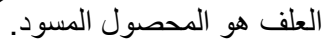

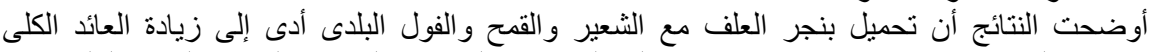

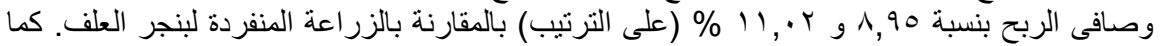

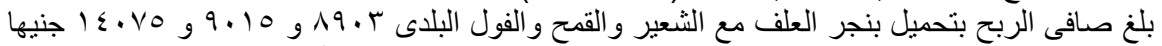

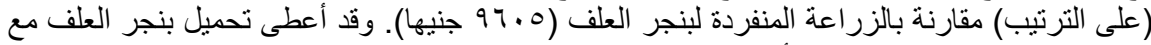

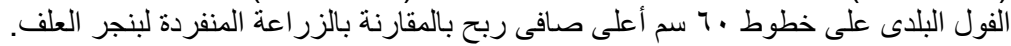

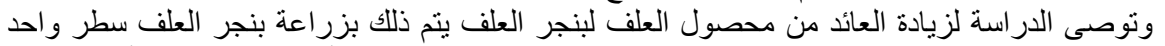

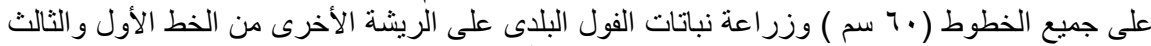
وترك الخط الذى يليه بدون تحميل و هكذا للحصول على أعلى عائد تحت ظروف الخد الدراسة. 
Table 1: Effect of cropping systems, ridge width and their interactions on fodder beet yield and its attributes, as well as, yields of barley, wheat and faba bean during two seasons and the combined analysis.

\begin{tabular}{|c|c|c|c|c|c|c|c|c|c|c|c|c|c|c|c|c|c|c|c|c|c|}
\hline \multirow[t]{2}{*}{ Characters } & \multicolumn{3}{|c|}{$\begin{array}{l}\text { Root length } \\
\quad(\mathrm{cm})\end{array}$} & \multicolumn{3}{|c|}{$\begin{array}{l}\text { Root diameter } \\
\text { (cm) }\end{array}$} & \multicolumn{3}{|c|}{$\begin{array}{c}\text { Root } \\
\text { weight/plant } \\
(\mathrm{kg})\end{array}$} & \multicolumn{3}{|c|}{$\begin{array}{l}\text { Root yield of } \\
\text { fodder beet } \\
\text { (ton/faddan) }\end{array}$} & \multicolumn{3}{|c|}{$\begin{array}{c}\text { Grain yield of } \\
\text { barley } \\
\text { (ardab/faddan) }\end{array}$} & \multicolumn{3}{|c|}{$\begin{array}{c}\text { Grain yield of } \\
\text { wheat } \\
\text { (ardab/faddan) }\end{array}$} & \multicolumn{3}{|c|}{$\begin{array}{c}\text { seed yield of } \\
\text { faba bean } \\
\text { (ton/faddan) }\end{array}$} \\
\hline & $\begin{array}{l}60 \\
\mathrm{~cm}\end{array}$ & $\begin{array}{l}120 \\
\mathrm{~cm}\end{array}$ & Mean & $\begin{array}{l}60 \\
\mathrm{~cm}\end{array}$ & $\begin{array}{l}120 \\
\mathrm{~cm}\end{array}$ & Mean & $\begin{array}{l}60 \\
\mathrm{~cm}\end{array}$ & $\begin{array}{l}120 \\
\mathrm{~cm}\end{array}$ & M & $\begin{array}{l}60 \\
\mathrm{~cm} \\
\end{array}$ & $\begin{array}{l}120 \\
\mathrm{~cm}\end{array}$ & Mean & $\begin{array}{l}60 \\
\mathrm{~cm} \\
\end{array}$ & $\begin{array}{l}120 \\
\mathrm{~cm}\end{array}$ & Mean & $\begin{array}{l}60 \\
\mathrm{~cm}\end{array}$ & $\begin{array}{l}120 \\
\text { cm }\end{array}$ & Mean & $\begin{array}{l}60 \\
\mathrm{~cm} \\
\end{array}$ & $\begin{array}{l}120 \\
\mathrm{~cm}\end{array}$ & lean \\
\hline \multicolumn{22}{|c|}{ First season 2009/2010 } \\
\hline odder beet + & 27.75 & 26.00 & 26.87 & 13.25 & 12.75 & 13.00 & 1.25 & 1.22 & 1.23 & 38.41 & 37.28 & 37.84 & 4.85 & 5.03 & 4.94 & -- & - & -- & - & -- & -- \\
\hline Fodder beet + wheat & 26.25 & 25.75 & 26.00 & 12.00 & 11.25 & 11.62 & 1.23 & 1.20 & 1.21 & 37.08 & 36.21 & 36.64 & - & - & - & 5.86 & 5.61 & 5.73 & - & -- & - \\
\hline Fodder beet + faba bean & 29.00 & 28.00 & 28.50 & 14.50 & 14.00 & 125 & 1.34 & 1.32 & 1.33 & 42.07 & 41.05 & 41.56 & - & -- & - & - & - & -- & 1.28 & 1.35 & 1.31 \\
\hline Average of intercropping & 27.66 & 26.58 & 27.12 & 13.25 & 12.66 & 12.95 & \begin{tabular}{|l|l|}
1.27 \\
\end{tabular} & 1.24 & 1.25 & 39.18 & 38.18 & 38.68 & 4.85 & 5.03 & 4.94 & \begin{tabular}{|l|}
5.86 \\
\end{tabular} & \begin{tabular}{|l|}
5.61 \\
\end{tabular} & 5.73 & 1.28 & 1.35 & 1.31 \\
\hline Sole planting & 31.00 & 31.00 & 31.00 & 16.00 & 16.00 & 1600 & 1.42 & 1.42 & 1.42 & 47.43 & 47.43 & 47.43 & 16.69 & 16.69 & 16.69 & 18.83 & 18.83 & 18.83 & 4.08 & 3.08 & 4.08 \\
\hline Average of ridge width & 29.33 & 28.79 & 29.06 & 14.62 & 14.33 & 14.47 & 1.34 & 1.33 & 1.33 & 43.30 & 42.80 & 43.05 & 10.77 & 10.86 & 10.81 & 12.34 & 12.22 & 12.28 & 2.68 & 2.71 & 2.69 \\
\hline $\begin{array}{l}\text { LSD at } 0.05 \text { Intercropping } \\
\text { LSD at } 0.05 \text { Ridge width } \\
\text { LSD at } 0.05 \text { Interaction }\end{array}$ & & $\begin{array}{l}1.93 \\
\text { NS } \\
\text { NS }\end{array}$ & & & $\begin{array}{l}3.13 \\
\text { NS } \\
\text { NS }\end{array}$ & & & $\begin{array}{l}0.03 \\
0.01 \\
\text { NS }\end{array}$ & & & $\begin{array}{l}2.17 \\
0.58 \\
\text { NS }\end{array}$ & & & $\begin{array}{l}3.26 \\
\text { NS } \\
\text { NS }\end{array}$ & & & $\begin{array}{l}3.16 \\
\text { NS } \\
\text { NS }\end{array}$ & & & $\begin{array}{l}0.35 \\
\text { NS } \\
\text { NS }\end{array}$ & \\
\hline \multicolumn{22}{|c|}{ Second season 2010/2011 } \\
\hline et + barley & 26.25 & 25.50 & 25.87 & 3.40 & 12.60 & 13.00 & 1.21 & 1.19 & 1.20 & 38.25 & 37.50 & 37.87 & 4.60 & 4.96 & 4.78 & $=$ & - & - & - & - & - \\
\hline Fodder b & 25.75 & 24.25 & 25.00 & 12.47 & 11.77 & 12.12 & 1.20 & 1.18 & 1.19 & 37.75 & 36.75 & 37.25 & -- & -- & -- & 5.63 & 5.53 & 5.58 & -- & -- & -- \\
\hline Fodder beet + faba bean & 29.50 & 28.75 & 29.12 & 14.55 & 13.35 & 13.95 & 1.29 & 1.27 & 1.28 & 42.85 & 41.32 & 42.08 & - & - & - & - & - & -- & 1.41 & 1.32 & 1.36 \\
\hline Average of intercropping & 27.16 & 26.16 & 26.66 & 13.47 & 12.57 & 15 & 1.23 & 1.21 & 1.22 & 39.61 & 38.52 & 39.06 & 4.60 & 4.96 & 4.78 & 5.63 & 5.53 & 5.58 & 1.41 & 1.32 & 1.36 \\
\hline ole planting & 30.90 & 30.90 & 30.90 & 15.50 & 15.50 & & 1.34 & 1.34 & 1.34 & 47.12 & 47.12 & 47.12 & 16.56 & 16.56 & 16.56 & 18.68 & 18.68 & 18.68 & 4.33 & 4.33 & \begin{tabular}{|l|l|}
4.33 \\
\end{tabular} \\
\hline Average of ridge width & 29.03 & 28.53 & 28.78 & 14.48 & 14.03 & 14.2 & 1.28 & 1.27 & 1.27 & 43.36 & 42.82 & 43.09 & 10.58 & 10.76 & 10.67 & 12.15 & 12.10 & 12.12 & 2.87 & 2.8 & 2.84 \\
\hline $\begin{array}{l}\text { LSD at } 0.05 \text { Intercropping } \\
\text { LSD at } 0.05 \text { Ridge width } \\
\text { LSD at } 0.05 \text { Interaction }\end{array}$ & & $\begin{array}{l}2.60 \\
0.59 \\
\text { NS }\end{array}$ & & & $\begin{array}{l}1.75 \\
0.58 \\
\text { NS }\end{array}$ & & & $\begin{array}{l}0.01 \\
0.01 \\
\text { NS }\end{array}$ & & & $\begin{array}{l}1.53 \\
0.49 \\
\text { NS }\end{array}$ & & & $\begin{array}{l}1.66 \\
\text { NS } \\
\text { NS }\end{array}$ & & & $\begin{array}{l}0.69 \\
\text { NS } \\
\text { NS }\end{array}$ & & & $\begin{array}{l}0.65 \\
\text { NS } \\
\text { NS }\end{array}$ & \\
\hline \multicolumn{22}{|c|}{ Combined analysis } \\
\hline Fodder beet + barley & 27.00 & 25.75 & \begin{tabular}{|l|l|}
26.37 \\
\end{tabular} & 13.32 & 2.67 & & 23 & 1.20 & \begin{tabular}{|l|}
1.21 \\
\end{tabular} & 38.32 & 37.39 & 37.85 & 4.72 & 4.99 & 4.85 & - & -- & -- & - & -- & - \\
\hline t + wheat & 26.00 & & 25.50 & 12.23 & 11.51 & & & 1.19 & 1.20 & 37.41 & 36.48 & 36.94 & - & -- & - & 5.74 & 5.57 & 5.65 & -- & - & \\
\hline Fodder beet + faba bean & 29.25 & 28.37 & 28.81 & 14.52 & 13.67 & 14.09 & 1.31 & 1.29 & 1.30 & 42.46 & 41.18 & 41.82 & -- & -- & - & -- & -- & -- & 1.34 & 1.33 & 1.33 \\
\hline Average of intercropping & 27.41 & 26.37 & 26.89 & 13.35 & 12.61 & 12.98 & 1.25 & 1.22 & 1.23 & 39.39 & 38.35 & 38.87 & 4.72 & 4.99 & 4.85 & 5.74 & 5.57 & 5.65 & 1.34 & 1.33 & 1.33 \\
\hline Sole planting & 30.95 & 30.95 & 30.95 & 15.75 & 15.75 & 15.75 & 1.38 & 1.38 & \begin{tabular}{|l|}
1.38 \\
\end{tabular} & 47.28 & 47.28 & 47.28 & 16.62 & 16.62 & 16.62 & 18.75 & 18.75 & 18.75 & 4.20 & 4.20 & \begin{tabular}{|l|}
4.20 \\
\end{tabular} \\
\hline dge width & 29.18 & 28.66 & 28.92 & 14.55 & 14.18 & 14.36 & 1.31 & 1.30 & 1.30 & 43.33 & 42.81 & 43.07 & 10.67 & 10.80 & 10.73 & 12.24 & 12.16 & 12.20 & 2.77 & 2.76 & 2.76 \\
\hline $\begin{array}{l}\text { LSD at } 0.05 \text { Intercropping } \\
\text { LSD at } 0.05 \text { Ridge width } \\
\text { LSD at } 0.05 \text { Interaction }\end{array}$ & & $\begin{array}{l}1.80 \\
0.50 \\
\text { NS }\end{array}$ & & & $\begin{array}{l}1.66 \\
0.37 \\
\text { NS }\end{array}$ & & & $\begin{array}{l}0.02 \\
0.008 \\
\text { NS }\end{array}$ & & & $\begin{array}{l}1.43 \\
0.41 \\
\text { NS }\end{array}$ & & & $\begin{array}{l}1.58 \\
\text { NS } \\
\text { NS }\end{array}$ & & & $\begin{array}{l}1.42 \\
\text { NS } \\
\text { NS }\end{array}$ & & & $\begin{array}{l}0.42 \\
\text { NS } \\
\text { NS }\end{array}$ & \\
\hline
\end{tabular}


Table 2: Relative yields and land equivalent ratio as affected by cropping systems, ridge width and their interactions during the two seasons and the combined analysis.

\begin{tabular}{|c|c|c|c|c|c|c|c|c|c|}
\hline \multirow{3}{*}{\begin{tabular}{|ll} 
& Characters \\
Treatments
\end{tabular}} & \multicolumn{6}{|c|}{ Relative yield } & \multirow{2}{*}{\multicolumn{3}{|c|}{ LER }} \\
\hline & \multicolumn{3}{|c|}{$\mathrm{L}_{\text {Fodder beet }}$} & \multicolumn{3}{|c|}{ Lintercrop } & & & \\
\hline & $60 \mathrm{~cm}$ & $120 \mathrm{~cm}$ & Mean & $60 \mathrm{~cm}$ & $120 \mathrm{~cm}$ & Mean & $60 \mathrm{~cm}$ & $120 \mathrm{~cm}$ & Mean \\
\hline \multicolumn{10}{|c|}{ First season $2009 / 2010$} \\
\hline Fodder beet + barley & 0.80 & 0.78 & 0.79 & 0.29 & 0.30 & 0.29 & 1.09 & 1.08 & 1.08 \\
\hline Fodder beet + wheat & 0.78 & 0.76 & 0.77 & 0.31 & 0.29 & 0.30 & 1.09 & 1.05 & 1.07 \\
\hline Fodder beet + faba bean & 0.88 & 0.86 & 0.87 & 0.31 & 0.33 & 0.32 & 1.19 & 1.19 & 1.19 \\
\hline Average of intercropping & 0.82 & 0.80 & 0.81 & 0.30 & 0.30 & 0.30 & 1.12 & 1.10 & 1.11 \\
\hline Sole planting & 1.00 & 1.00 & 1.00 & 1.00 & 1.00 & 1.00 & 1.00 & 1.00 & 1.00 \\
\hline LSD at 0.05 Intercropping & \multirow{2}{*}{\multicolumn{3}{|c|}{$\begin{array}{l}0.008 \\
0.008\end{array}$}} & \multirow{2}{*}{\multicolumn{3}{|c|}{0.01}} & \multicolumn{3}{|c|}{0.007} \\
\hline LSD at 0.05 Ridge width & & & & & & & \multirow{2}{*}{\multicolumn{3}{|c|}{$\begin{array}{c}0.004 \\
0.01\end{array}$}} \\
\hline LSD at 0.05 Interaction & & NS & & \multicolumn{3}{|c|}{0.01} & & & \\
\hline \multicolumn{10}{|c|}{ Second season $2010 / 2011$} \\
\hline Fodder beet + barley & 0.81 & 0.79 & 0.80 & 0.27 & 0.29 & 0.28 & 1.08 & 1.08 & 1.08 \\
\hline Fodder beet + wheat & 0.80 & 0.76 & 0.78 & 0.30 & 0.29 & 0.29 & 1.10 & 1.05 & 1.07 \\
\hline Fodder beet + faba bean & 0.90 & 0.87 & 0.88 & 0.32 & 0.30 & 0.31 & 1.22 & 1.17 & 1.19 \\
\hline Average of intercropping & 0.82 & 0.80 & 0.81 & 0.29 & 0.29 & 0.29 & 1.13 & 1.10 & 1.11 \\
\hline Sole planting & 1.00 & 1.00 & 1.00 & 1.00 & 1.00 & 1.00 & 1.00 & 1.00 & 1.00 \\
\hline LSD at 0.05 Intercropping & \multirow{2}{*}{\multicolumn{3}{|c|}{0.01}} & \multicolumn{3}{|c|}{0.01} & \multicolumn{3}{|c|}{0.006} \\
\hline LSD at 0.05 Ridge width & & & & \multirow{2}{*}{\multicolumn{3}{|c|}{0.01}} & \multirow{2}{*}{\multicolumn{3}{|c|}{$\begin{array}{l}0.003 \\
0.008\end{array}$}} \\
\hline LSD at 0.05 Interaction & \multicolumn{3}{|c|}{$\begin{array}{c}0.006 \\
0.01\end{array}$} & & & & & & \\
\hline \multicolumn{10}{|c|}{ Combined analysis } \\
\hline Fodder beet + barley & 0.80 & 0.78 & 0.79 & 0.28 & 0.29 & 0.28 & 1.08 & 1.08 & 1.08 \\
\hline Fodder beet + wheat & 0.79 & 0.76 & 0.77 & 0.30 & 0.29 & 0.29 & 1.09 & 1.05 & 1.07 \\
\hline Fodder beet + faba bean & 0.89 & 0.86 & 0.87 & 0.31 & 0.31 & 0.31 & 1.20 & 1.18 & 1.19 \\
\hline Average of intercropping & 0.82 & 0.80 & 0.81 & 0.29 & 0.29 & 0.29 & 1.12 & 1.10 & 1.11 \\
\hline Sole planting & 1.00 & 1.00 & 1.00 & 1.00 & 1.00 & 1.00 & 1.00 & 1.00 & 1.00 \\
\hline LSD at 0.05 Intercropping & \multirow{2}{*}{\multicolumn{3}{|c|}{$\begin{array}{l}0.007 \\
0.004\end{array}$}} & \multicolumn{3}{|c|}{0.003} & \multicolumn{3}{|c|}{0.006} \\
\hline LSD at 0.05 Ridge width & & & & \multirow{2}{*}{\multicolumn{3}{|c|}{$\begin{array}{c}\text { NS } \\
0.005\end{array}$}} & \multirow{2}{*}{\multicolumn{3}{|c|}{$\begin{array}{l}0.003 \\
0.008\end{array}$}} \\
\hline LSD at 0.05 Interaction & \multicolumn{3}{|c|}{0.01} & & & & & & \\
\hline
\end{tabular}


Table 3: Relative crowding coefficient (K) and Aggressivity (Agg) as affected by cropping systems, ridge width and their interactions, combined analysis.

\begin{tabular}{|c|c|c|c|c|c|c|c|c|c|c|c|c|c|}
\hline \multirow{3}{*}{ Treatments } & \multicolumn{9}{|c|}{ RCC } & \multicolumn{4}{|c|}{ Aggressivity } \\
\hline & \multicolumn{3}{|c|}{$\mathrm{Ka}$} & \multicolumn{3}{|c|}{$\mathbf{K b}$} & \multicolumn{3}{|c|}{$\mathrm{K}$} & \multicolumn{2}{|c|}{ Agg+ } & \multicolumn{2}{|c|}{ Agg- } \\
\hline & $60 \mathrm{~cm}$ & $120 \mathrm{~cm}$ & Mean & $60 \mathrm{~cm}$ & $120 \mathrm{~cm}$ & Mean & $60 \mathrm{~cm}$ & $120 \mathrm{~cm}$ & Mean & $60 \mathrm{~cm}$ & $120 \mathrm{~cm}$ & $60 \mathrm{~cm}$ & $120 \mathrm{~cm}$ \\
\hline Fodde & 1.06 & 0.94 & 1.00 & 1.58 & 1.71 & 1.64 & 1.67 & 1.60 & 1.63 & 0.85 & 0.41 & -0.85 & -0.41 \\
\hline Fodder beet + wheat & 0.94 & 0.84 & 0.89 & 1.76 & 1.69 & 1.72 & 1.6 & 1.41 & 1.5 & 0.43 & 0.41 & -0.43 & -0.41 \\
\hline Fodder beet + faba bean & 2.20 & 1.68 & 1.94 & 1.87 & 1.85 & 1.86 & 4.11 & 3.10 & 3.60 & 0.38 & 0.39 & -0.38 & -0.39 \\
\hline
\end{tabular}

Table 4: Financial return as affected by cropping systems, ridge width and their interactions (combined data across $2009 / 2010$ and $2010 / 2011$ seasons)

\begin{tabular}{|c|c|c|c|c|c|c|c|c|c|c|c|c|}
\hline \multirow[t]{3}{*}{ Characters } & \multicolumn{12}{|c|}{ Financial return } \\
\hline & \multicolumn{3}{|c|}{ Fodder beet } & \multicolumn{3}{|c|}{ Intercrops } & \multicolumn{3}{|c|}{ Total } & \multicolumn{3}{|c|}{ Net } \\
\hline & $\begin{array}{l}60 \\
\mathrm{~cm}\end{array}$ & $\begin{array}{l}120 \\
\mathrm{~cm}\end{array}$ & Mean & $\begin{array}{l}60 \\
\mathrm{~cm}\end{array}$ & $\begin{array}{l}120 \\
\mathrm{~cm}\end{array}$ & Mean & $\begin{array}{l}60 \\
\mathrm{~cm}\end{array}$ & $\begin{array}{l}120 \\
\mathrm{~cm}\end{array}$ & Mean & $\begin{array}{l}60 \\
\mathrm{~cm}\end{array}$ & $\begin{array}{l}120 \\
\mathrm{~cm}\end{array}$ & Mean \\
\hline Fodder beet + barley & 13412 & 13086 & 13249 & 1434 & 1516 & 1475 & 14846 & 14602 & 14724 & 9025 & 8781 & 8903 \\
\hline Fodder beet + wheat & 13093 & 12768 & 12930 & 2020 & 1960 & 1990 & 15113 & 14728 & 14920 & 9208 & 8823 & 9015 \\
\hline Fodder beet + faba bean & 14861 & 14413 & 14637 & 5324 & 5284 & 5304 & 20185 & 19697 & 19941 & 14319 & 13831 & 14075 \\
\hline Average of intercropping & 13788 & 13422 & 13605 & 2926 & 2920 & 2923 & 16714 & 16342 & 16528 & 10850 & 10478 & 10664 \\
\hline Sole planting of fodder beet & 15165 & 15165 & 15165 & -- & -- & -- & 15165 & 15165 & 15165 & 9605 & 9605 & 9605 \\
\hline
\end{tabular}

Prices of main products are that of 2011:

350 L.E./ton of fodder beet

304 L.E./ardab of barley

352 L.E./ardab of wheat

596 L.E./ardab of faba bean

Intercropping fodder beet with faba bean increased variable costs of intercropping culture $\mathbf{4 4 7 0}$ L.E. over those of sole fodder beet. 